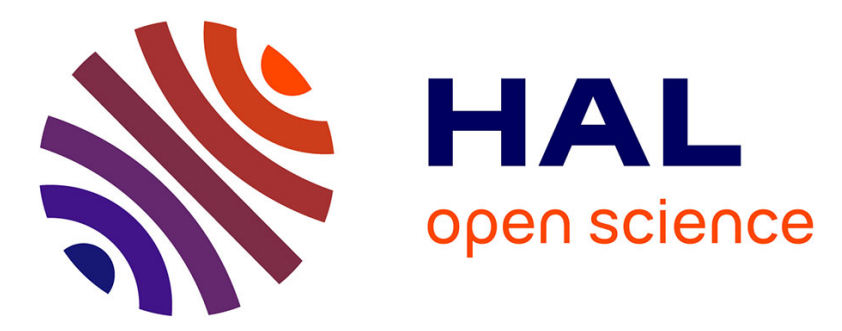

\title{
Beyond the "Norm Entrepreneur" Model: Rwanda, Darfur, and Social Sanction among UN Diplomats
}

David Ambrosetti

\section{To cite this version:}

David Ambrosetti. Beyond the "Norm Entrepreneur" Model: Rwanda, Darfur, and Social Sanction among UN Diplomats. Global Society, 2010, 24 (2), pp.151-171. 10.1080/13600821003626377 . halshs-00474254

\section{HAL Id: halshs-00474254 \\ https://shs.hal.science/halshs-00474254}

Submitted on 20 Sep 2019

HAL is a multi-disciplinary open access archive for the deposit and dissemination of scientific research documents, whether they are published or not. The documents may come from teaching and research institutions in France or abroad, or from public or private research centers.
L'archive ouverte pluridisciplinaire HAL, est destinée au dépôt et à la diffusion de documents scientifiques de niveau recherche, publiés ou non, émanant des établissements d'enseignement et de recherche français ou étrangers, des laboratoires publics ou privés.

$$
\text { Copyright }
$$




\section{Beyond the 'Norm Entrepreneur' Model: Rwanda, Darfur, and Social Sanction among UN Diplomats}

\section{DAVID AMBROSETTI}

When investigating why state decision-makers opt for intervention in the heart of armed violence abroad, many scholars refer to new humanitarian norms appearing among state officers, particularly within the UN. In these approaches, 'norm entrepreneurs', and the high risks of public opprobrium they are supposed to induce, stand at the front stage of normative change. Compliance with newly promoted normative ideas seems totally bereft of professional risks, though. This paper intends to bring back in a dimension of norms that is central in sociology: social sanction. Investigating how social sanctions are practically enacted among diplomats at the UN precisely provides useful data to detect the many norms that prosper beyond - and before - normative enterprises, and to assess why the humanitarian idea and the recent 'responsibility to protect' still have weak normative effects, practically speaking. The international failures in Rwanda and more recently in Darfur deserve re-examination in this prospect.

\section{Introduction}

When investigating why state decision-makers opt for interventionist lines of action in the heart of armed violence that affects non citizens abroad, many scholars refer to new norms appearing among state officers, particularly within international organisations and multilateral 
arenas. A large debate in International Relations (IR) concerns the 'responsibility to protect' (R2P) as a new norm on the making.

The R2P lays for a large part on the hurting memories of the 1994 genocide of Tutsis and moderate Hutus in Rwanda. Rwanda became an archetype of international dismissal and disinterest in front of unbearable evil, and by the same token one of the favoured arguments for those eager to stress the responsibility of the 'international community' to stop, if not impede, such large-scale violence that occurs within the borders of sovereign states. Rwanda, like Munich, has shown the price that has to be paid for weakness, or disinterest.

At the UN headquarters, many lessons were said to be learned from Rwanda for conflict resolution and peacebuilding. In the current process of institutionalisation of $\mathrm{R} 2 \mathrm{P}$, the 'Rwandas' still symbolise the situations where no state, and particularly no powerful state, is ready to engage national or support international deployment to attempt to stop ongoing largescale violence, as the current framing of the Darfur issue since 2003 shows $^{1}$.

In this paper, I do not intent to discuss the importance to promote the R2P as such. My point is rather to target some uses of the notion of norm that paradoxically hinder the proper understanding of the central role existing norms played in failures like Rwanda, as these failures constantly threaten the process of institutionalisation of new normative ideas like R2P. Indeed, what marshals many IR analyses concerning political decision-making and international interventionism in overseas conflict is that they tend to sweep aside a dimension of norms that is central in sociology: social sanction. In these studies, the 'choice' to comply with new norms seems totally bereft of risks for those called upon changing their behaviours, 
particularly when they are foreign policy decision-makers. I champion here a more sociological understanding of norms at odds with this norm entrepreneur model.

The only form of sanction admitted by realists is embedded in the ordinary use of power between state leaders, through bilateral incentives (commitments and rewards) and deterrence (threats and punishments), but they deny any normative foundation within such power relations. Liberals, on the contrary, heed primarily the relation between political leaders and their constituencies, and the values, norms and preferences they share. This latter prospect reduces the risks faced by foreign policy decision-makers to the sole risks of public opprobrium. These risks always conform to the Habermassian model of the 'public sphere', which focuses on the 'public' ex-post approbation or contest, that is, the liberal-grounded relation between accountable governments on the one hand, and enlightened opinion leaders and public reactions on the other hand ${ }^{2}$. In the realm of overseas interventionism, this model instigated a huge amount of work on what has collectively labelled as the 'CNN effect' although it often remains imprecise about the opportunities and risks induced by this public pressure for political leaders' own positions and careers and the (national and international) political rivalries at stake in any media mobilisation of the kind. In this view, 'norm entrepreneurs' stand at the front stage of normative change, since the question is deemed to be an issue of emission of norms, at the expense of a deeper understanding of the existing norms that rule the reception of promoted norms.

Apparently obvious, this model is fraught with many assumptions that obliterate the understanding of normative obstacles to the diffusion of norms on the making, like R2P. For norms do not only reside on the side of normative enterprises diffused by opinion leaders and activists through media and other liberal institutions. Norms do underlie every social practice. 
They exist wherever practices are collectively expected and socially sanctioned among groups. By no means does the whole political society (either national or global) organized through liberal institutions constitute the only group that may generate expectations and enact sanctions. Social sanction lies in many specific groups. It supports the everyday practices among each of these groups. This includes political decision makers' practices, and even those practices aimed at pursuing one's 'interests' realists investigate. Norms deserve to be so detected, as they infringe on the normative enterprises evolution. They are attendant to risks that each member of a specific group perceives from his or her fellows. These are more precisely risks to experience negative social sanction among the group, or in other words to fail to make others' positive social sanction linger. I lay out how, if sociologically well defined and cautiously unfolded, social sanctions precisely provide useful data to detect the presence of the great number of norms that prosper beyond - and before - normative enterprises. Normative enterprises shall thus not be equated with norms. In fact, they need be investigated in order to ascertain whether or not they have engendered norms as such.

Returning to the failure in Rwanda and the making of new norms of humanitarian intervention and R2P, an indispensable dimension thus resides in the following question: To which extent may the compliance with promoted normative ideas in specific situations among specific groups constitute a potential deviance and generate risks for those invited to adopt new behaviours and comply with new promoted norms? Realist scholars would invoke individual interests. I will refer to norm compliance, to the absence or presence of collective pressure among specific groups.

In a first section, I trace the relative absence of theorisation on individual risks of deviance and negative social sanction in political decision making analysis to the dominant 
interpretations of norms that prosper in IR. I conclude this section on the common model these interpretations are tuned with, the 'norm entrepreneur' model. The second section recalls the Rwandan case and tries to locate the risks the decision makers in charge of 1994 Rwanda were exposed to. Initial empirical objections are addressed to this norm entrepreneur model. In a third section, I assess another incidence of this very model, which equates individual risks of social sanction to the risk of public opprobrium. Again, empirical limits of this model come into question. Finally, I expose, first from the epistemological point of view and then from the empirical point of view, what the practical norm and social sanction approach can bring to the study of international practices.

\section{Norms and Risks in IR analysis on Humanitarian Intervention}

Norms (which are social by definition) and individual risks do not get along well in IR theory. One reason lies in the division of intellectual labour among IR specialists. Realists, on the one hand, tend to monopolise the scientific interest for power and conflict. They thus cultivate a strong disposition to track political leaders' calculations on the opportunities and risks attendant to their political competitions, and refuse to link these opportunities and risks to supposedly shared values and 'norms', both of which they frequently equate, and despise as 'subjective' and intangible variables (opposed to 'objective' material interests) ${ }^{4}$. Liberals, on the other hand, give priority to the rational incentives for cooperation between individuals and states, and to the shared values, principles and institutions that are supposed to foster such cooperation. They thus tend to underestimate the dimension of risks and collective pressure and to focus on rational opportunities and consensual ideas. 
A second reason lies in the types of actors that IR analyses focus on. Here again, realists differ from liberals, in that the relation between states is for them the only 'social interaction' (could they agree with this terminology) that warrants consideration, whereas for liberals, actors from the 'civil society' - be they organised on a strict national basis or on a transnational basis - do also deserve attention, as they shape political leaders' preferences, through internal liberal and democratic institutions or through international organisations and transnational networks.

As they are keen to borrow findings from social theory and sociology, constructivist scholars analyse political actors and their practices through the lens of constructed social identities and roles and through constructed social norms attached to these identities and roles $^{5}$. Attention is thus paid to the quest for conformity to social norms, this logic of appropriateness well described by James March and Johan Olsen ${ }^{6}$. Quite surprisingly, even if this analytical prospect immediately implies to acknowledge the inherent risks of deviance for social agents, these risks are not so well theoretically developed in IR constructivist theories ${ }^{7}$, and they are not even empirically scrutinised in constructivist case studies, particularly when dealing with state decision-making processes.

The insufficient theorisation on the relation between norms and individual risks for decision makers in IR is of direct salience to studies on humanitarian intervention and R2P. In this realm, the realist perspective is mainly represented by scholars who hold a strong experience as practitioners and favour the concrete issues faced by national decision makers, for whom they exert - in a typical problem-solving perspective - their realist reasoning and skills on the strategies of the belligerents and the "international community" ${ }^{9}$. Insignificant role is acknowledged to norms in these studies ${ }^{9}$. 
A larger amount of IR research on this matter corresponds to a liberal and constructivist trend, though. Priority has been given to the excavation of the occurrences and the diffusion of these 'norms' of humanitarian intervention and R2P, as these notions are more and more publicly invoked by state decision-makers and UN officials. Humanitarian interventions are becoming the 'normal' thing to do, at the expense of former normal behaviours, like non interference in internal affairs, and new practices are emerging within diplomacies and armed forces ${ }^{10}$. This normative change would stem from argumentation and moral persuasion and their effects on the previously dominant norms. It would also lean on collective pressure among peers, and concern for reputation in larger audiences, thanks to transnational actors and particularly global media.

On the theoretical side, such assumption underlies the often quoted 'life-cycle' of norms proposed by Martha Finnemore and Kathryn Sikkink (1998: 895), from explicit efforts to persuade others to a wider acceptance of the promoted norm in a cascade form and finally norm internalisation ${ }^{11}$. In this constructivist perspective, norms seem to incite scholars' interest as long as they result from "norm entrepreneurs", and particularly transnational actors and advocacy networks from the "civil society' ${ }^{12}$. This view assumes that normative change results first and foremost from 'believers', from what Ethan Nadelmann called 'transnational moral entrepreneurs"13. These moral enterprises consist in "persuad[ing] foreign audiences" that the promoted set of norms (and particularly 'prohibition regimes' in the case of Nadelmann) "reflects a widely shared or even universal moral sense, rather than the peculiar moral code of one society." 14 In Finnemore and Sikkink's analysis, the ideational and ethical origin of these entrepreneurs' motivations plays the central role, and leads them to elaborate 
rational strategies in order to "reconfigure preferences, identities, or social contexts" for others $^{15}$.

Surreptitiously, norms tend to be equated with normative beliefs, with ethical values, and frequently with universal and liberal normative beliefs and values many scholars may precisely find hardly contestable, at least in pacified, Western-style liberal democracies ${ }^{16}$. This entailed severe reactions from practitioners and from the poststructuralist and the critical side of the IR discipline, which point to the social structures of domination that spread out alongside these normative enterprises calling for interventionist - sometimes very intrusive and patronising - practices on behalf of humanitarian beliefs ${ }^{17}$.

On the empirical side, some would add useful questions and/or empirical insights on the effects of these normative enterprises and the obstacles it encounters, particularly concerning $\mathrm{R} 2 \mathrm{P}^{18}$. The absence of foreign intervention in Darfur has instigated, since summer 2004, such questioning about the obstacles hampering the effectiveness of $\mathrm{R} 2 \mathrm{P}$ at the $\mathrm{UN}$ regarding this violent conflict ${ }^{19}$. A promising direction has driven scholars to investigate the normative foundations of these obstacles, in the form of local norms obstructing the local appropriation of global norms on the making ${ }^{20}$.

But the enduring obstacles in the diffusion and appropriation of such globally promoted norms among politicians, diplomatic and military decision makers, and international bureaucrats in charge of international conflict management rarely inspire analyses through the lens of incompatible norms shared by specific groups involved in this realm. 


\section{Indifference and Genocide in Rwanda: where were the risks?}

The refusal of the UN Security Council to react during the genocide and the 'politicide' organised by the Hutu-Power leadership in spring 1994 in Rwanda against the Rwandan Tutsis and Hutu opponents is largely known. The reasons may reside in the absence of strategic interests but also in potentially conflicting norms.

\section{Disinterest}

Numerous studies have been dedicated to understand how the 1994 genocide could happen, from the Rwanda political society point of view and/or from the international diplomatic and aid community perspective. They show how the different actors of the international community' even refused to take further preventive or protective measures as the 1993 Arusha peace agreement experienced increasing challenges from the ruling party and political forces openly hostile to the agreement, the Rwandan military and the armed youth groups linked to these political forces, but also from the rebels of the Rwanda Patriotic Front (RPF) ${ }^{21}$. These challenges seemingly served to test the UN determination and capabilities to react, was large-scale violence to spread in front of the UN soldiers deployed in Rwanda (the UNAMIR). Yet, UN reactivity remained tremendously low. Its apathy turned to an incredible dismissal after the beginning of the genocide, particularly when the UNSC decided to withdraw the larger part of the UNAMIR on April 21.

Not surprisingly, this appalling international indifference has not induced - as far as I know - research aimed at proving that diplomats and UN civil officers in charge of the Rwanda dossier at that time did not intimately share the humanitarian principles and values 
calling upon humanitarian intervention in such extreme case. This quite naïve perspective would hardly satisfy the methodological requirements for empirical investigation in social research, as Ronald Krebs and Patrick Jackson recall when they warn against the temptation to track persuasion and beliefs in political actors' claims ${ }^{22}$. Nevertheless, it sharply outlines how supporters of the 'norm entrepreneur' perspective tend to disregard behaviours that differ notably from indisputable normative enterprises, and to neglect the normative foundation of these behaviours.

The reasons of this overall indifference around the world particularly during the first three weeks of the genocide and even afterwards have now been better grasped. The first element is the lack of strategic interests perceived by the agents of the most influent states and the permissive environment for indifference. None of the members of the UNSC were impeded to act because of hard national interests during the 1990-1994 Rwandan conflict and during the genocide - apart from the representatives of the Rwandan government, who were serving on the UNSC from January 1994 till the rebellion's victory in July, and echoed the positions of the Rwandan interim government responsible of the genocide. On the contrary, with some nuances concerning France and Belgium, foreign interests were apparently low by then, particularly the case of the United States ${ }^{23}$.

But a second dimension, a potentially normative one, may be outlined. In 1997, Michael Barnett proposed a precious 'insider' insight on U.S. and UN diplomatic decision making during this period ${ }^{24}$. He pointed to the peculiar atmosphere existing within the $\mathrm{UN}$ in the immediate aftermath of the U.S.-UN humiliating withdrawal from Somalia following successive military defeats in June and October 1993. As an "expert" of Rwanda at the U.S. mission to the UN by then, Barnett firstly recalls how he and his colleagues got convinced 
that UN reputation had to be protected as it was again severely threatened by another potential failure broadcasted worldwide only six months after the Mogadishu battle of 3 October 1993. Indeed, the Arusha peace agreement had just burst out as the genocide began and the belligerents returned to war. The Secretary-General remained astonishingly atone about what should be done, even when ten Belgian blue helmets were killed by the Rwandan Presidential Guard along with the Prime Minister of the Broad Based Transitional Government (Agathe Uwilingiyimana) in April 7, the day after the murder of the Rwandan president Juvénal Habyarimana that sparked the genocide. And none of the members of the UNSC offered immediate contribution for a reinforced UN mission aimed at thwarting the spread of the killings and restoring UN authority for the respect of the existing peace agreement ${ }^{25}$. The fear of a UN letting its military personnel be paralysed and killed without reaction and losing all credibility in the face of its troops contributors and financial backers, including the U.S. (contributing to $30 \%$ of the UN peace operations budget at that time), constituted the major concern about the ongoing genocide among the U.S. mission to the UN by then ${ }^{26}$.

\section{Conflicting Norms?}

An 'intellectualist' interpretation of norms focused on the 'norm entrepreneur' model suggests the following hypothesis, which tells a well known story. At that time, the 'norm' of humanitarian intervention was emerging, although founded on philosophical, religious and legal precedents. Its promoters were at work in order to sway military, diplomats and UN civil servants at the UN, despite the latter's traditional norms and values, that is, 'realist', statecentric and power-maximizing ones. These agents were said to be progressively admitting this norm, and even internalising it, particularly those from Western states when the Cold War ended. They 'proved' it first in Iraqi Kurdistan in April 1991 and then in Somalia in 
December 1992. The UN benefited from an increased support for multidimensional operations and showed a greater concern for the humanitarian dimension in armed conflicts. The UN and the humanitarian norm entrepreneurs support each others. But in Somalia, Bosnia or Rwanda, unexpected difficulties intermingled and induce new doubts among the promoters, weakening this normative enterprise. Protecting the UN reputation could have been a hard decision that diplomats and UN officers took as they were facing an inextricable conflict of norms and weighed each one's chances of success. The R2P recently emerged in order to give new impulse to this enterprise and to completely reconcile the humanitarian norm entrepreneurs with the UN.

Michael Barnett's account calls this narrative into question, however. After analysing his own choices within the U.S. mission to the UN, Barnett got convinced that UNSC diplomats and UN bureaucrats easily seized and invoked this argument of protecting the UN reputation in order to cloth their renouncement and bureaucratically built indifference for ongoing humanitarian disasters in the universal, transcendental values associated with the UN. The bureaucratisation of social work among the UN was causing these agents to progressively identify with the whole institution, with its secular values but also with its own stakes, its own risks and its own frontiers between the important and the unimportant. The people the UN was supposedly working for did not appear so easily on UN agents' cognitive and emotional maps in their everyday work. This is a common feature of modern bureaucracies ${ }^{27}$. Barnett's description of how his U.S. colleagues and interlocutors at the UN came to feel exasperated and annoyed by those calling for intervention (without offering any of the necessary material for that), and even to convince themselves that the UN could not do anything for people that "was not able to help themselves" (were they to endure rapid and systematic extermination), is edifying ${ }^{28}$. 
In other terms, one cannot easily ascertain that protecting the UN reputation engendered at that time - nor today - completely 'normal' things to do, behaviours that every single diplomat serving to the UNSC knew he or she had to adopt as an obvious one. At least two indepth inquiries boldly documented how the U.S. State Department, but also the UN Secretariat and the humanitarian organisations engaged in UN peacekeeping activities, felt particularly anxious to fend off the fierce attacks addressed to the White House by a U.S. Congress notoriously hostile to the UN at that time ${ }^{29}$. But it was first and foremost a national politics issue between the Administration and the Congress rather than a concern for U.S. reputation among transnational advocacy networks and international organisations.

This brings to investigate the absence of risks of negative sanction from 'public opinion' elites, which constitute the backbone of both constructivist and liberal approaches mentioned above.

\section{Normative Entrepreneurs and Public Opprobrium in distant violence: Empirical Limits}

As I put it above, IR constructivist literature on normative change within international organisation and multilateral conflict management often rely on the consideration that political decision-makers face the risks to experience collective opprobrium from their peers or from national and international public opinions ${ }^{30}$. Let me mention here the analysis Brent Steele devoted to the Darfur case and apply it to Rwanda. It outlines that the risks induced by public pressure in support of norm enterprises still deserve better understanding and empirical excavation in order to be attested. 
Public Opprobrium and Ontological Security

Brent Steele's recent analysis of 'reflexive discourse' and 'ontological security' in U.S. foreign policy and the case of Darfur offers a sophisticated interpretation of this model of sanction through public opprobrium applied to international conflict management ${ }^{31}$. Following Anthony Giddens and Erik Erikson, Steele pays much attention to the importance of the ideas of the self for social actors, the importance of their collectively acknowledged identities, which are entrenched in socially constructed narratives and provide them with a feeling of security, of 'ontological security' about what they are, regarding others. Consequently, they feel a profound fear not to be collectively acknowledged these primal identities anymore, which implies a sense of protecting the social narratives upon which their identities are built. Steele thus assumes that middle powers and other less powerful actors can promote a new norm if they find a way to weaken the ontological security of the constituencies and leaders of a powerful state. This normative enterprise requires convincing the latter that the narrative upon which their common identities are built calls for compliance with the norm these less powerful normative entrepreneurs precisely intend to promote.

When discussing international action in Darfur, Steele notices that the U.S. government qualified the violence in Darfur as genocide ${ }^{32}$. He also observes that American constituencies would largely feel their leaders forfeit their own ideas of self, their identities, were they convinced by credible actors that incontestable genocide was being perpetrated before their faces and that well-known sets of actions were available to the U.S. administration in order to make it stop. Such information, Steele foresees, would deeply damage the narrative that harnesses their identity on the international scene, and would harshly clout their own 
ontological security, entailing a large demand for more efficient protective measures for Darfuri people. Unfortunately, Steele concludes, credible actors (he thinks of middle powers with high credibility like the Canadian government) have seemingly not achieved to hit American constituencies' ontological security yet.

Although incontestably innovative, Steele's theoretical claim could have better convinced were it applied to the 1994 genocide in Rwanda rather than in contemporary Darfur. One can hardly allege that no voice has been echoed in the global media concerning Darfur since February 2003, particularly in 2004 and 2006. 'Save Darfur' coalition (a large campaign in the media worldwide) and many celebrities from the show business have targeted Western publics to change Western states' foreign policies toward Darfur ${ }^{33}$. Since these activists and celebrities both qualified the situation as genocide and condemn the apathy in Western states in such critical situation, referring to the shameful international dismissal during the 1994 genocide in Rwanda, their action may correspond to an attempt to cause ontological insecurity for American and Western publics.

From Darfur Back to Rwanda: Factual Inconsistencies and Data Shortage

One can allege that 'Save Darfur' campaign and the many voices that have been heard concerning Darfur may have engendered new constraints for U.S. diplomatic decisionmakers. Did this public pressure caused the latter to adopt new practices, and if it is the case, did such new practices make these decision makers come nearer the norms of humanitarian intervention and responsibility to protect on behalf of which activists speak about Darfur? Specialists like Alex de Waal purport that such initiatives failed - so far - to bring new leverage for political action to end the conflict in Darfur ${ }^{34}$. Eric Heinze convincingly claims 
that the official qualification of genocide by the U.S. Congress and then the U.S. Administration did result from this media campaign, whereas the majority of states and organisations were - and remain today - prudent or reluctant to use too quickly this qualification of genocide, sometimes for political reasons, but above all for lack of irrefutable proofs, so far $^{35}$. He then explains the discrepancy between this haste in the U.S. and this reluctance elsewhere, as the consequence of the proximity of the former American Administration with the 'faith-based' activists committed in the Darfur 'cause', particularly before the election of 2004 and the mid-term election of 2006. This official qualification thus corresponded to a strong rhetoric move from the G.W. Bush administration that intended to sharply contrast with the constant posture of denial adopted by the Clinton administration during the incontestable genocide in Rwanda in spring $1994^{36}$. Yet, this move was designed to placate important political movements for the President Bush. But rather than opening a new era of U.S. official involvement for the resolution of the conflict in Darfur, it allowed to water the internal pressure down and to avoid important change in the U.S. practices toward Sudan, as subsequent decisions and practices have shown till today ${ }^{37}$.

On the contrary, the 1994 genocide in Rwanda could have attested opinion leaders' potential force in order to produce ontological insecurity and U.S. stronger involvement, even if this eventually did not happened. As Samantha Power outlined, media coverage remained bereft of opinion leaders fraught with the responsibility to mobilise worldwide for a rapid and large deployment in Rwanda ${ }^{38}$. In 1994, Rwanda coverage skyrocketed from May on in the news media, relatively to its low level before this date. But the qualification of genocide remained rare till July, when the genocide was merely over (the RPF became military victorious on July 17). The U.S. administration's refusal to use and let use the term 'genocide' to the UN is well known ${ }^{39}$. The graph below illustrates this relative disinterest before 6 April 
1994, and the initial reluctance to speak of genocide in April and May in media coverage, with the case of an influent journal in the corridors of the UN in New York, the New York Times.

Graph 1: New York Times articles mentioning Rwanda in the text (per month), from 1 October 1990, to 31 December 1994.

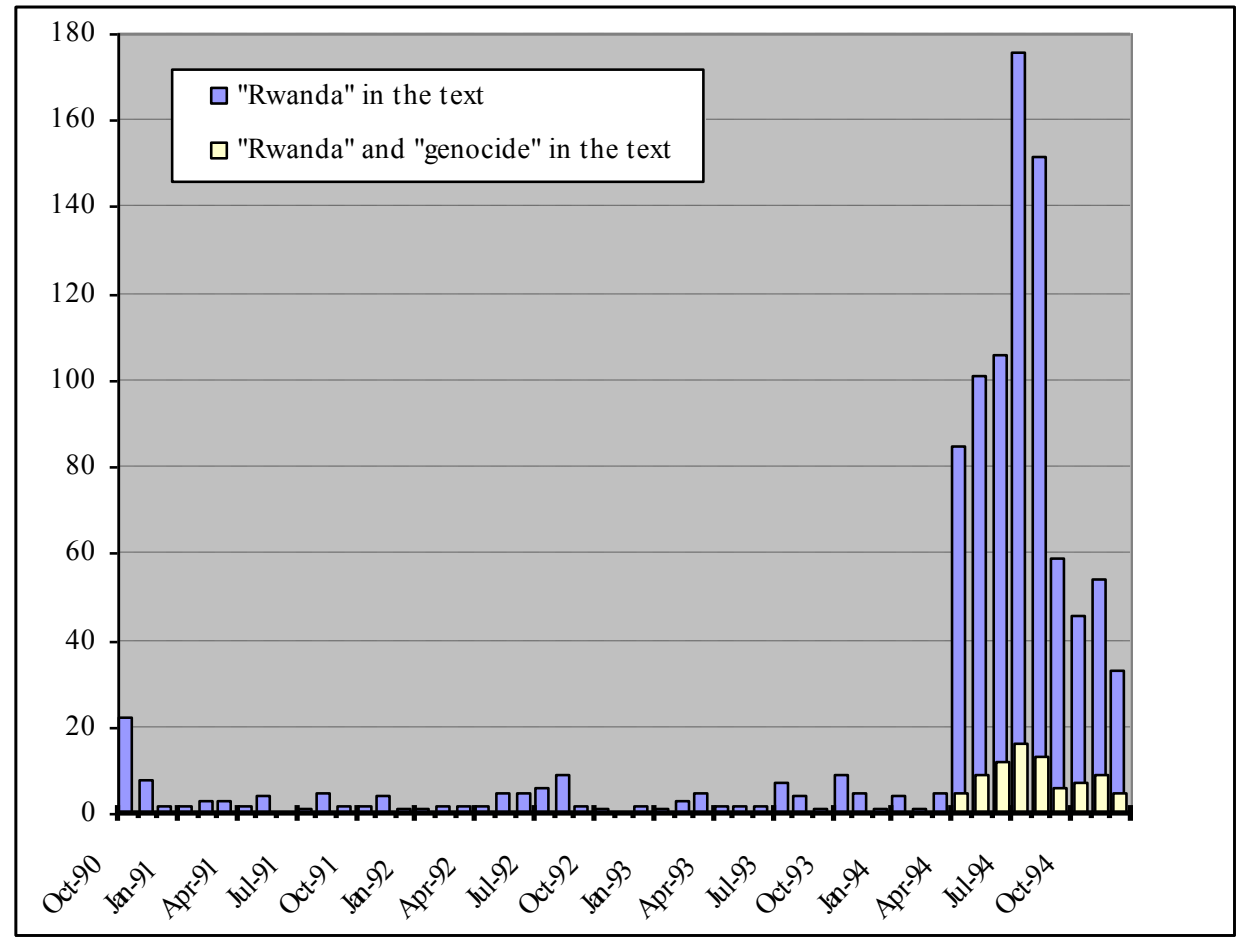

(C) David Ambrosetti

Thoroughly, Rwanda did not entail a strong public, transnational mobilisation during the genocide. By then, no large vivid campaign was led in world media in the name of Rwanda. Nothing vets to ascertain that such public mobilisation with audible calls for precise action would have prevailed over the U.S. inspired and UN-endorsed taboo over the 'g-word'. But the very U.S. demand for this blackout within the UN proves how the Clinton administration felt itself exposed to potential public pressure that would have force to do more about Rwanda and would have deepen the tensions with the U.S. Congress. It contrasts with the apparent ease with which the G. W. Bush administration talked about genocide in Darfur and did not blatantly modify its action toward Darfur and the peace processes in Sudan. 
These two examples of Darfur and Rwanda rapidly compared disclose how hazardous it might be to take the clout of public mobilisation through large media coverage for granted, without deeper empirical investigation, when assessing risks endured by political and diplomatic decision-makers who deal with overseas violence and armed conflicts. I now intend to expose and rapidly illustrate different assumptions on norms and social sanction that help refurbish the analysis of political decision making among diplomats.

\section{Among diplomats at the UN: an Ambivalent Source of social sanction}

In Rwanda, withdrawing and standing by did not appear as the risky option to many UN officials and diplomatic decision makers concerned. On the contrary, the perceived risk resided in intervening. The interpretation of norms shall first be reframed in its epistemological assumptions, in order to empirically grasp such norm-grounded risks which constitute an aberration from the humanitarian normative enterprise point of view.

Individual Risks beyond Invoked Norms: Framing the Practical Norms and Social Sanction Hypothesis

What would have happened had UNSC or coalitions of states promptly intervene militarily and politically will never be known. One hypothesis is that it could have induced, after initial precarious success, another visible failure and ashamed withdrawal engendering large discredit toward international 'humanitarianism'. In such case, obviously, the prevention of a forthcoming genocide would never be placed to the credit of the eventually unsuccessful 
interveners, as nobody would have known a genocide was about to occur in Rwanda. What is known, on the contrary, is that the decision makers in charge did apparently not experience any negative consequence on their careers afterwards ${ }^{40}$. This seems to confirm they were right to position the risks to intervene over the risks to stand by. Here is the main conclusion I draw from specialised literature (confirmed by my own investigations) and I now wish to focus on, according to the theoretical questioning that drives this discussion.

It is here crucial to understand what brought so many decision makers and bureaucrats to collectively make this 'bet', to understand what sort of information permitted it, and where this information resided. For instance, did the UN under secretary general for peacekeeping operations of the time, Kofi Annan, 'know' that such failure experienced by the UNAMIR under his formal responsibility would not bring his professional ascension within the UN hierarchy to an immediate end? A hard choice arose among those in charge of Rwanda. Conditions of this choice were for a large part entirely contingent: recent UN and U.S. humiliation in Somalia, U.S. Congress hostility toward the inflating costs of UN peace operations, lack of strategic interests for UNSC members, peace operation contributing states concerned with possible fatalities among their troops, lack of interest for Rwanda amidst the UN Secretary, tensions between the U.S. administration and the UN Secretary-General, Boutros Boutros-Ghali, good prejudices towards the Habyarimana regime among international aid organisations, etc.

One needs to remind well established results from sociological and anthropological theory, which point to the existence of norms immerged in the everyday practices. These norms do stir up individual risks of negative social sanction for 'deviance' even if they do not lean on a well rationalised ethical adhesion to abstract values. Indeed, social knowledge does not only 
consist in discursively-formulated intellectual constructions, including ethical ones, but it also encompasses all knowledge that is mobilised by individuals in their everyday life. Most of this everyday knowledge does not need be firmly intellectually elaborated in the agents' minds to be operational, to be practically available in the course of action ${ }^{41}$.

Like other forms of social knowledge, norms are also deeply rooted in this dimension of the everyday. Social agents do not constantly mobilise and face verbally-formalised prescriptions based on explicit normative beliefs and ethical arguments. The norms they follow in their everyday activity also reside in their practical rationality, and are not less prescriptive. This perfectly applies to agents and practices on the international political scene $^{42}$. Now, how can one scrutinise norms if a great many number of them do not appear as such in the social agents' verbal practices, and remain 'concealed' in a sense? ${ }^{43}$ Here intervene two intertwined elements of norms from this sociological prospect.

The first one is the centrality of regularities. Regularities in behaviours not only attest the probable existence of norms within a group, rather than pure chance, but they fashion each member's cognition and expectations as one gets socialised among the group and builds one's own identities and rules and interests consistently with one's environment. In that sense, Peter Katzenstein's definition of norms, focused on collective expectations ${ }^{44}$, avoids the ambiguity embedded in Finnemore and Sikkink's one, which only mention "standard $[\mathrm{s}]$ of appropriate behaviour for actors with a given identity" without detailing where 'appropriateness' dwells ${ }^{45}$. Another indispensable tool is the dichotomy between 'normative belief' and 'behavioural norms' usefully recalled by Neta Crawford ${ }^{46}$, as every single normative belief does not entail changes in existing behavioural norms, and countless behavioural norm owe their existence to other social mechanisms than enterprises aimed at promoting normative beliefs. As Onuf 
summarized it, following Ludwig Wittgenstein, "regularities are the key" 47 . This brings to recall the importance of institutions in social life ${ }^{48}$.

Social sanction constitutes the second determinant feature of practical norms: norms require the constant support of others, of the group, through the collective responses to one's practices in the course of the everyday interactions within the group. But what precedes triggers out an interpretation of sanction that differs significantly from the public opprobrium model. Since social sanction leans on the practices of the group in response to an 'initial' behaviour from one of its members, therefore these 'sanctioning' practices, as any other social practice, can be enacted by the other members of the group without any preliminary ethical assessment of it. They would only mobilise the practical knowledge they have collected in observing the social regularities within their group.

What precedes invites to question the norm entrepreneur and public opprobrium models in at least four of their assumptions. Indeed social pressure and sanction do not only result from a verbally rationalised, logic-grounded assessment of decisions and practices amid the group with regard to the collective preferences, including ethics, values and principles of its members. Positive or negative social sanction can also be exerted by the group toward one of them without any highly rationalised intention to do so at the individual level.

Secondly, the probability for the researcher to find this kind of 'sanctioning practices' founded on practical norms (that is, collective expectations that remain partly or totally out of ethical or even intellectual elaboration) will seemingly soar when dealing with day-to-day "little" choices and practices enacted by decision-makers. This counters a second assumption, that make many scholars investigate pressure and risks of sanction only in the approbation or 
rebuff of announced goals and intentions and 'great' decisions (to send troops, to support a UN peace operation, to establish a regime of sanctions against a government, etc), and neglect many other everyday practices that are also exposed to someone's endorsement.

A third assumption underlying this model of norm entrepreneur warrants further questioning as well: social sanction of political decision makers seems to work in one direction, according to a one-shot action/reaction model. It eludes that any collective reaction itself results from the aggregate of individual responses performed in specific normative environments with specific risks attendant to them. In other words, both one's 'actions' and others' 'reactions' stem from the previous observation of regularities within specific groups, from the observation of repeated practices and their consequences for both the one who acts and those who witness this 'initial' act and are expected to react in a way or another.

Probably the most significant and confusing assumption is to consider the (national or globally media-connected) 'public', i.e. the sum of national constituencies, as the only group empowered enough in order to vie against national political decision-makers and to sanction them, according to the political institutions decision-makers and national constituencies share $^{49}$. Yet, one can easily conceive and observe that different behavioural norms rule different groups, beyond the sole major normative beliefs shared by the political society as a whole and institutionalised within its legal system.

Indeed, social agents, including decision makers and international and national bureaucrats, belong to various social groups. They forge their respective identities and social positions as they interact and get socialised within these different groups ${ }^{50}$. In so doing, they simultaneously access to social resources through the statuses and the material and symbolic 
support they are acknowledged among each of these groups, and internalise social rules including collective expectations (norms) - that secure the reproduction of their social resources $^{51}$. They learn what they ought to enact and banish, in order to sideline negative social sanction. By the same token, they become dependent on the reproduction of these resources, or more precisely, on the reproduction of the very behaviours that make these resources linger amid the given groups - that is, positive social sanction. Consequently social practice is unavoidably fraught with the risks of loosing these resources ${ }^{52}$.

\section{Diplomats and Collective Social Sanctions at the UN: Anthropological insights}

The anthropological stand Michael Barnett adopted in order to revisit his own experience within the U.S. mission to the UN during the Rwandan genocide of 1994 gives some elements to support my notion of practical norm lying on social regularities and social sanction. Indeed, Barnett well described how he versed himself in the codes of conduct and working standards so that he got tuned with his colleagues" expectations in order to become first an "expert" on Rwanda in their eyes, and then a "native" of the $\mathrm{UN}^{53}$. The amount and the pace of work that had to be done entailed a large part of this socialisation. The other part was the fear of "sanctions" from his colleagues for "disloyalty" "54. In so doing, Barnett shared with his fellows diplomats, if not a same culture ${ }^{55}$, at least he same collective expectations about the situations and the possible practices.

Iver Neumann proposed another anthropological insight from an 'insider' perspective that does confirm the weight of peer collective expectations and sanctions. It shows that colleagues within the ministry of foreign affairs, and secondly diplomats of other countries, constitute the major targeted audience in the everyday fabric of diplomatic discourses, rather 
than the larger public 'outside'. What matters in these discourses is to fend for "ministry identity building" on the international diplomatic scene ${ }^{56}$.

A fundamental conclusion must be drawn according to norms of humanitarian intervention and R2P: for these normative ideas to become actual norms, in the practical sense I champion here, routinised positive social sanction behaviours and risks of negative social sanction must be regularly observed by individual 'conflict managers', as an incessant proof of existing collective expectations on behaviours inspired by these normative enterprises. Such routine and risks would mould the pace of decision makers' everyday work. These collective expectations among specific groups must refer to specific social positions in specific situations. They shall induce specific risks of negative social sanction in a given group, that is, specific threats to one's social resources and, at last, one's positions (or even identities) among the given group.

Empirically, this prospect requires identifying and investigating specific social positions among specific groups. Returning to the Rwandan case, I will consider in the following the decision-making position of Permanent Representative of the U.S. to the UN, that is, the appointment of ambassador heading the U.S. Mission to the UN.

\section{The Search for Acceptable Practices about Rwanda}

The normative environment of a U.S. head of mission to the UN is composed of many potential groups that may nurture congruent but also conflicting expectations toward him or her on specific dossiers discussed at the UNSC table. Concerning Rwanda, expectations and perceived risks were low, as I already put it. When Madeleine Albright inherits the two-year 
lasting Rwandan conflict in January 1993, humanitarian concern is limited to the assistance of Rwandan displaced people. But Rwanda does not retain U.S. and other Western countries' attention for the military interventionist stand they are developing since the end of the Cold War on humanitarian grounds against the norm of non interference and the 'legal' prohibition of the use of force by the UN Chart ${ }^{57}$.

The apparent absence of actual collective expectations among diplomats to the UN concerning a systematic protection of civilians as such does not mean that nobody expects anything from the U.S. ambassador to the UN concerning a dossier like Rwanda. The production of statements and resolutions by the UNSC shows that the ambassadors serving on the UNSC 'know' they are expected from larger audiences to keep on taking position and manifesting interest. Their colleagues would hardly tolerate to see the only international instance charged to regulate international violence and maintain world peace and stability frontally disregarding one armed conflict and openly announcing they chose to abandon people exposed to grave violence. In Barnett's opinion, that was the only use of pursuing the UNSC meetings, generating a flood of documents and statements, and maintaining it "seized of the matter" during the genocide ${ }^{58}$.

In a same vein, the observation of their individual statements at the UNSC table shows the importance they give to the expression of humanitarian concern and compassion toward civilians affected by violence. This kind of diplomatic discourse fulfils requirements embedded in practical regularities among diplomats, as other forms of diplomatic discourse ${ }^{59}$. It can thus be interpreted as a practical norm, a socially expected and sanctioned practice it would be risky to underestimate ${ }^{60}$. 
Admittedly, as the silence over the ongoing genocide persisted, a few ambassadors at the table of the UNSC expressed horrified reactions in an uncommon tone, particularly in the case of Colin Keating from New Zealand (who was chairing the UNSC in April 1994) and Karel Kovanda from the Czech Republic ${ }^{61}$. Barnett called them the "conscience of the Council", "in both derision and admiration" he added, as these delegations did not propose any of their own troops to support the implored operation ${ }^{62}$. According to him, though their critics addressed to members who resisted intervention, they were "insinuating that the United States should take the lead" to "hide their own unwillingness to get involved"63.

Obviously, these critics intended to impulse a normative pressure toward the only members of the UNSC that had enough military forces of projection and the experience to intervene in Sub-Saharan Africa. More than a clear collective reaction of negative sanction, these critics must be rather understood following the 'norm enterprise' model. The dramaturgic (yet justified) tone chosen by Karel Kovanda of her public declarations was clearly directed at external audiences, as she knew she was speaking in a public, film recorded, meeting. The purpose was probably not to get her own statement largely broadcasted but to sow the seeds of more external attention on what was happening in Rwanda and within the UNSC, that is, to insufflate a new public pressure.

Paradoxically, this powerful declaration proves that no practical, actually collectively expected norm has been infringed among UNSC members concerning Rwanda. In 1994, 'humanitarian interventions' were indeed a quite recent practice, or better said, an old practice (military intervention in peripheral conflicts) that was sprouting thanks to recently emerged motives (humanitarian). Importantly, the Czech and other UNSC delegations did not denounce a sudden and unforgivable change of behaviour from the U.S. administration, and 
other UNSC powerful members, corresponding to a clear refusal to continue well defined and routinised practices aimed at protecting civilians in armed conflicts in general, and in Rwanda in particular. They may rather have felt unease about their incapacity to foresee and prevent such outbreak of extreme and rapidly spreading violence in one of their working dossiers where UN was military present to maintain peace. They may also have feared an immediate interruption in the current development of the humanitarian normative enterprise and of the UNSC activities in regional conflicts and crises. But these were anything but normal, collectively expected and well routinised practices.

Reactions among UNSC members blatantly showed this collective unease, rather than a well experienced collective reaction conforming to well identified collective expectations and routines. Barnett confirmed that the U.S. demand for silence at the UN and the incredible decision to withdraw the major part of the UNAMIR amidst the killings (resolution 912, April 21) entailed discomfort as the genocide became obvious to everyone at the UNSC table and even violent attacks from some members ${ }^{64}$. This suggests a final hypothesis: the discomfort may have generated reflexive posture and learning on how to prevent not only the Mogadishu scenario of shameful military debacle sending a signal of weakness, but also the Rwandan scenario of an outrageous inaction of already deployed UN troops, inspired by high selectivity between risk-worthy and risk-unworthy 'crises', even when an indisputable genocide is on progress. This outrage will often be recalled with gravity in following reports on this matter within the UN and other international organisations ${ }^{65}$.

This unease may have induced at least one noticeable normative change in the realm of UN peace operations in the aftermath of these events. When the French President decided, in 15 June 1994, to launch a military operation in Rwanda (with the formal endorsement of the 
UNSC in 22 June), when Australia engaged its own troops to support the UN operation in Timor Leste in 1999, when the United Kingdom did a similar thing (only with informal consent from the UNSC and the Secretariat) in Sierra Leone in 2000-2002, when France again successfully mobilised the European Union, and notably Germany, in order to deploy a EUled operation in Democratic Republic of Congo in 2003, and again in 2006, all of these diplomacies were warmly granted by the U.S. and swallowed by the other members of the $\mathrm{UNSC}^{66}$ as they were intervening when UN troops were challenged and exposed to the risk of shameful withdraw. As they appeared as an immediately available solution against this risk, these operations opened a new practice without much negative reactions. Since this practice actually lingers, it becomes an actual collective expectation within the UNSC so that delegations supporting a UN deployment somewhere should be ready to send troops to protect this operation ${ }^{67}$. Of course this solution raises many ethical difficulties, as it gives preeminence to the UN members that possess military capacities to protect a UN operation already deployed. But precisely, it is not progressing as a fully ethically-grounded normative enterprise, but as a practice in the process of repetition, of routinisation, that is, of normalisation, in a practical sense.

\section{Conclusion}

In IR investigations on decision-making processes in the realm of international conflict management and interventionism, compliance with norms is often weeded out of risks for the individuals who act, for instance the decision-makers who are about to decide. The division of intellectual work among IR specialists gives some clue on this absence of risks in theoretical thinking on international norms, as it digs an important gap between the realist interpretation 
of norms (norms are helpless) on the one hand, and the liberal and constructivist one (norms are entrenched in the sole sanction exerted by national and international civil societies and public opinions toward their ruling elites through shared liberal political institutions) on the other hand. Temptation is even high to equate norms with the sole normative enterprises one feels sympathetic with, neglecting the normative basis of behaviours incompatible with, or hostile toward, these promoted 'norms'.

Precisely, the UN response over the civil conflict and the genocide in Rwanda in 19901994 exposes practices that notoriously failed to comply with, or even betrayed, the norm enterprise championing humanitarian intervention.

In this paper, I claimed that sociology of practice allowed overcoming this dichotomy. The proposed shift is driven by an epistemological disagreement with the very sense given to the notion of norm. Norms are often interpreted as behaviours consciously promoted - usually through argumentative means, particularly in the scientific field or the legal one - by actors who adhere to intellectually-elaborated and ethically-grounded ideas, ideas about what is good and about what the world should be. This 'norm entrepreneur' model primarily locates risks on public opinion and the fear of public 'bashing'.

However, this model hampers an appropriate sociological understanding of social sanction, as the latter does not necessarily lies in the relation between governments' objectives and 'public' values and preferences if one observes the work of high ranked state officers in a day-to-day basis. I suggested that the kind of explicit and intended sanction (approbation or reprobation) from 'the public' against decision-makers is by large less frequent than the social sanction entrenched in the latter's everyday work, and in the 
responses they face from specific groups in the course of their day-to-day interactions, according to specific collective expectations (be they verbally rationalised or not) attached to collectively acknowledged identities and social positions.

I then proposed what this prospect, focused on practical norms and everyday social sanction, could bring to the empirical investigation and to the theoretical understanding of international practices fashioned among peers in multilateral arenas like the United Nations Security Council. This analytical frame firstly assumes that existing collective expectations fraught with risks of negative social sanction shared by specific groups of decision makers and civil servants in charge of the regulation of overseas conflicts may play an important role in the following fact, recalled by the current conflicts in Darfur or in Democratic Republic of Congo: for the worse or for the better, the humanitarian idea and its latter product currently in vogue, the responsibility to protect, have not entailed so far new collective expectations about precise practices deemed to be systematically enacted by diplomats in order to assure effective protection for civilians in situations of violence well specified according to precise parameters ${ }^{68}$, and this despite at least forty years of large media coverage of, and academic and diplomatic interest for, these 'humanitarian crises' caused by peripheral armed conflicts, whether internal or regional.

\footnotetext{
${ }^{1}$ Alex J. Bellamy, "Whither the Responsibility to Protect? Humanitarian Intervention and the 2005 World Summit”, Ethics and International Affairs, Vol. 20, No. 2 (2006), pp. 143-169.

2 Jürgen Habermas, The Structural Transformation of the Public Sphere: an Inquiry into a Category of Bourgeois Society, translated by Thomas Burger with the assistance of Frederick Lawrence (Cambridge, Polity, 1992).

${ }^{3}$ Piers Robinson, The CNN Effect: the Myth of News, Foreign Policy and Intervention (London, New York: Routledge, 2002); Andrew Hoskins and Ben O'Loughlin, Television and Terror: Conflicting Times and the Crisis of News Discourse (Basingstoke: Palgrave Macmillan, 2007).
} 
${ }^{4}$ Jack Snyder, “Anarchy and Culture: Insights from the Anthropology of War”, International Organization, Vol. 56, No. 1 (2002), pp. 7-45, particularly pp. 7-9.

${ }^{5}$ Alexander Wendt, Social Theory of International Politics (Cambridge: Cambridge University Press, 1999).

${ }^{6}$ James March and Johan Olsen, "The Institutional Dynamics of International Political Orders", International Organization Vol. 52, No. 4 (1998), pp. 943-69.

${ }^{7}$ Vaughn P. Shannon, "Norms Are What States Make of Them: the Political Psychology of Norm Violation", International Studies Quarterly, Vol. 44, No. 2 (2000), pp. 293-316.

${ }^{8}$ Chester A. Crocker, Fen Osler Hampson and Pamela Aall (eds.), Turbulent Peace. The Challenge of Managing International Conflict (Washington: United States Institute of Peace Press, 2001); Chester A. Crocker, Fen Osler Hampson and Pamela Aall, Taming Intractable Conflicts. Mediation in the Hardest Cases (Washington: United States Institute of Peace Press, 2004); Stephen J. Stedman, Donald Rothchild and Elizabeth M. Cousens (eds.), Ending Civil Wars. The Implementation of Peace Agreements (International Peace Academy / Center for International Security and Cooperation, Boulder: Lynne Rienner, 2002).

${ }^{9}$ Stephen J. Stedman, “Introduction”, in Stedman, Stephen J., Donald Rothchild and Elizabeth M. Cousens, op. cit. pp. 19-20. See a similar view in Chester A. Crocker, Fen Osler Hampson et Pamela Aall, Taming Intractable Conflicts, op. cit., pp. 26-28.

${ }^{10}$ Martha Finnemore, “Constructing Norms of Humanitarian Intervention”, in Peter Katzenstein (ed.), The Culture of National Security (New York: Columbia University Press, 1996), pp. 153-185; Neta Crawford, Argument and Change in World Politics: Ethics, Decolonization, and Humanitarian Intervention (Cambridge: Cambridge University Press, 2002); Thomas Risse, Stephen Ropp and Kathryn Sikkink, The Power of Human Rights (Cambridge, Cambridge University Press, 1998); Thomas G. Weiss, Military-Civilian Interactions: Intervening in Humanitarian Crises (Lanham: Rowman and Littlefield, 1998); Nicholas Wheeler, Saving Strangers. Humanitarian Intervention in International Society (Oxford: Oxford University Press, 2000).

${ }^{11}$ Martha Finnemore and Kathryn Sikkink, "International Norms Dynamics and Political Change”, International Organization, Vol. 52, No. 4 (1998), pp. 887-917.

${ }^{12}$ Amitav Acharya, "How Ideas Spread: Whose Norms Matter? Norm Localization and Institutional Change in Asian Regionalism", International Organization, Vol. 58, No. 2 (2004), pp. 239-275, particularly p. 242.

${ }^{13}$ They are "groups that mobilise popular opinion and political support both within their host country and abroad, $[\ldots]$ stimulate and assist in the creation of like-minded organizations in other countries, and $[\ldots]$ play a significant role in elevating their objective beyond its identification with the national interests of their 
government.” Ethan Nadelmann, “Global Prohibition Regimes: The Evolution of Norms in International Society”, International Organization, Vol. 44, No. 4 (1990), pp. 481-482.

${ }^{14}$ Ibid. Nadelmann borrowed from Howard Becker the notion of "moral entrepreneurs", agents "who 'operate with an absolute ethics' in seeking to create new rules to do away with a perceived great evil'. Howard Becker, Outsiders: Studies in the Sociology of Deviance (New York: Free Press, 1963), p. 148, quoted in Nadelmann, op. cit., p. 482.

${ }^{15}$ Finnemore and Sikkink, op. cit., p. 888.

${ }^{16}$ David Halloran Lumsdaine, Moral Vision in International Politics: The Foreign Aid Regime, 1949-1989 (Princeton, Princeton University Press, 1993); Peter Viggo Jakobsen, “The Transformation of United Nations Peace Operations in the 1990s. Adding Globalization to the Conventional 'End of the Cold War Explanation'”, Cooperation and Conflict, Vol. 37, No. 3 (2002), pp. 267-282.

${ }^{17}$ Adam Branch, "Against Humanitarian Impunity: Rethinking Responsibility for Displacement and Disaster in Northern Uganda", Journal of Intervention and Statebuilding, Vol. 2, No. 2 (2008), pp. 151-173; David Chandler, Empire in Denial: The politics of State-Building, Ann Arbor: Pluto Press, 2006. Debrix, François (1999) Re-Envisioning Peacekeeping: the United Nations and the Mobilization of Ideology (Minneapolis: University of Minnesota Press, 1999); Mark Duffield, "Getting Savages to Fight Barbarians : Development, Security and the Colonial Present', Conflict, Security and Development, Vol. 5, No. 2 (2005), pp. 141-159; Roland Paris, "International Peacebuilding and the 'Mission Civilisatrice' ", Review of International Studies, Vol. 28, No. 4 (2002), pp. 637-656; Razack, Sherene, Dark Threats and White Knights: the Somalia Affair, Peacekeeping and the New Imperialism (Toronto, University of Toronto Press, 2004). See a similar critic applied in another realm of international politics in Acharya, op. cit., pp. 242-244.

${ }^{18}$ Bellamy, op. cit., 2006; Sandra J. Maclean, David R. Black and Timothy M. Shaw (eds.) A Decade of Human Security: Global Governance and New Multilateralisms (Aldershot \& Burlington: Ashgate, 2006); Shahrbanou Tadjbakhsh and Anuradha M. Chenoy, Human Security: Concepts and Implications (London \& New York: Routledge, 2007).

${ }^{19}$ Hugo Slim, "Dithering over Darfur? A preliminary review of the international response", International Affairs, Vol. 80, No. 5 (2004), pp. 811-828; Paul D.Williams and Alex J. Bellamy, "The responsibility to protect and the crisis in Darfur", Security Dialogue, Vol. 36, No.1 (2005), pp. 27-47.

${ }^{20}$ Acharya, op. cit. 
${ }^{21}$ African Rights, Rakiya Omar et al., Rwanda. Death, despair and defiance, London: African Rights, 1994, pp. 94-95; Alison Des Forges, Human Rights Watch, Leave None to Tell the Story: Genocide in Rwanda (New York: Human Rights Watch, 1999), pp. 123-129 and 141-147; André Guichaoua (ed.), Les crises politiques au Burundi et au Rwanda, 1993-1994: Analyses, faits et documents (Villeneuve d'Ascq: Université des Sciences et Technologies de Lille / Karthala, 1995); Gilbert Khadiagala, "Implementing the Arusha Peace Agreement on Rwanda", in Stedman, Rothchild and Cousens, op. cit., pp. 87-106; Samantha Power, A Problem from Hell: America and the Age of Genocide, New York: Basic Books, 2002, pp. 342-345; Gérard Prunier, The Rwanda Crisis, 1959-1994: History of a Genocide, London: Hurst, 1995, p. 168-169.

${ }^{22}$ Ronald R. Krebs and Patrick Thaddeus Jackson, “Twisting Tongues and Twisting Arms: The Power of Political Rhetoric", European Journal of International Relations, Vol. 13, No. 1 (2007), pp. 35-66.

${ }^{23}$ Michael N. Barnett, "UN Security Council, Indifference, and Genocide in Rwanda", Cultural Anthropology, Vol. 12, No. 4 (1997), pp. 551-578.

${ }^{24}$ Ibid.

${ }^{25}$ Ibid., pp. 558-62.

${ }^{26}$ Barnett, ibid., p. 571.

${ }^{27}$ Ibid., pp. 562-570, quoting Michael Herzfeld.

${ }^{28}$ Ibid., p. 569. Samantha Power reported the strategy adopted by the U.S. mission to the UN, which consisted in ensuring the belligerent that any failure to respect the Arusha peace agreement would cause the U.S. to demand the withdrawal of the UN mission in Rwanda. And so they did. She also attested the moral justifications the U.S. diplomats in charge brandish for their inaction during the genocide. Power, op. cit., p. 347, and pp. 383-384. ${ }^{29}$ Organization of African Unity, Ketumile Masire, Rwanda: The Preventable Genocide, Report of the International panel of eminent seven personalities to investigate the 1994 genocide in Rwanda and the surrounding events (Addis Ababa, 7 July 2000), pp. $81-85$ (from § 12-32 to § 12-51); Power, op. cit., notably pp. $341-342$.

${ }^{30}$ Jakobsen, op. cit., p. 269, pp. 271-274; Alastair I. Johnston, “Treating International Institutions as Social Environments', International Studies Quarterly, Vol. 45, No. 4 (2001), p. 493; Shannon, op. cit., p. 297.

${ }^{31}$ Brent Steele, "Making Words Matter: The Asian Tsunami, Darfur, and 'Reflexive Discourse' in International Politics", International Studies Quarterly, Vol. 51, No. 4 (2007), pp. 901-925. 
${ }^{32}$ On July 22, 2004, the two chambers of the U.S. Congress officially declared that genocide was going on in Darfur. President G.W. Bush and Colin Powell endorsed this declaration in September 2004, notwithstanding the persistent controversy about the qualification of mass crimes committed in Darfur.

${ }^{33}$ Alex de Waal, “The Humanitarian Carnival: a Celebrity Vogue”, World Affairs, Vol. 171, No. 2 (2008), pp. 43-55; Rebecca Hamilton and Chad Hazlett, “ 'Not On Our Watch”, The Emergence of the American Movement for Darfur", in Alex de Waal (ed.), War in Darfur and the Search for Peace (Cambridge: Global Equity Initiative, Harvard University; London: Justice Africa, 2007), pp. 337-366.

${ }^{34}$ Alex de Waal, "The Humanitarian Carnival”, op. cit.

${ }^{35}$ Eric Heinze, "The Rhetoric of Genocide in U.S. Foreign Policy: Rwanda and Darfur Compared”, Political Science Quarterly, Vol. 122, No. 3 (2007), pp. 359-383.

${ }^{36}$ Ibid., pp. 368-372.

${ }^{37}$ Ibid., pp.376-378. See also de Waal (ed.), War in Darfur, op. cit. Nonetheless, the U.S. support to the UNSC resolution 1593 in March 2005, which invited the International Criminal Court to investigate humanitarian crimes in the Darfur region less than three months after the Sudanese government concluded a historic peace agreement with the South Sudanese rebels to put an end to a 20-year war, can been interpreted as a result of this lobbying enterprise. More "realist" practitioners often talk of an attempt to prompt regime change in Sudan. ${ }^{38}$ Power, op. cit., pp. 373-377, and p. 383.

${ }^{39}$ Ibid., pp. 358-364. United Nations, Ingvar Carlsson et al., Report of the Independent Inquiry into the actions of the United Nations during the 1994 genocide in Rwanda (New York: United Nations, S/1999/1257, 15 December 1999), pp. 40-41; Barnett, op. cit., p. 574. ${ }^{40}$ Organization of African Unity, op. cit., p. $84 \S 12.48$; Power, op. cit., pp. 373-374.

${ }^{41}$ Peter Berger and Thomas Luckmann, The Social Construction of Reality: A Treatise in the Sociology of Knowledge (New York: Penguin Press, 1971), pp. 26-27; Pierre Bourdieu, The Logic of Practice (Stanford: Stanford University Press, 1990), pp. 48-54, pp. 103-104; Anthony Giddens, The Constitution of Society: Outline of the Theory of Structuration (Cambridge: Polity, 1984), pp. 3-7; Erving Goffman, Frame Analysis: An Essay of the Organization of Experience (New York: Harper and Row, 1974). A new 'turn' in social science has blazed from this prospect, a "practice turn”. Theodore R. Schatzki, Karin Knorr Cetina and Eike von Savigny, The Practice Turn in Contemporary Theory (New York: Routledge, 2001); Bernard Williams, In the beginning was the deed: Realism and Moralism in Political Argument (Princeton; Oxford: Princeton University Press, 2005); 
Iver B. Neumann, "Returning Practice to the Linguistic Turn: The Case of Diplomacy", Millennium, Vol. 31, No. 3 (2002), pp. 627-651. In IR, it has been heralded essentially by Nicholas Onuf and Friedrich Kratochwil. ${ }^{42}$ Nicholas G. Onuf, "Everyday Ethics in International Relations”, Millennium, Vol. 27, No. 3 (1998), pp. 669694.

${ }^{43}$ Giddens, op. cit., p. 23.

${ }^{44}$ Katzenstein (ed.), op. cit., p. 5, defined norms as "collective expectations for the proper behavior of actors within a given identity".

${ }^{45}$ Finnemore and Sikkink, op. cit. p. 891.

${ }^{46}$ Crawford, op. cit., p. 40.

${ }^{47}$ Nicholas G. Onuf, World of Our Making. Rules and Rule in Social Theory and International Relations (Columbia: University of South Carolina Press, 1989), p. 45.

${ }^{48}$ Berger and Luckmann, op. cit., notably pp. 77-87; John W. Meyer, John Boli and George M. Thomas, "Ontology and Rationalization in Western Cultural Account", in George Thomas, John W. Meyer, Francisco O. Ramirez and John Boli (eds), Institutional Structure: Constituting State, Society, and the Individual (Newbury Park, CA: Sage, 1987), p. 13.

${ }^{49}$ Andrew Moravcsik, "Integrating International Theories and Domestic Theories of International Bargaining", in Peter B. Evans, Harold K. Jacobson and Robert D. Putnam (eds.), Double-Edge Diplomacy: International Bargaining and Domestic Politics (Berkeley: University of California Press, 1993), pp. 3-42.

${ }^{50}$ See Giddens' discussion of "role strain" recalled by Bruce Cronin, "The Paradox of Hegemony: America's Ambiguous Relationship with the United Nations", European Journal of International Relations, Vol. 7, No. 1 (2001), p. 111. Anthony Giddens, Central Problems in Social Theory: Action, Structure and Contradiction in Social Analysis (London: Macmillan Press, 1979), pp. 118-119.

${ }^{51}$ This is the sociological analytical model I develop in my book: David Ambrosetti, Normes et rivalités diplomatiques à l'ONU. Le Conseil de sécurité en audience [Diplomatic Norms and Rivalries at the UN: The Security Council in Audience] (Bruxelles: P.I.E. Peter Lang, 2009).

${ }^{52}$ Bourdieu, op. cit., particularly p. 80. Bourdieu spoke of social capitals, not social resources.

${ }^{53}$ Barnett, op. cit., pp. 551-556. The specific universe of contemporary bureaucracy shaped a large part of this normative convergence. Barnett deepened this view in his following work: Michael Barnett and Martha Finnemore, Rules for the World: International Organizations in Global Politics (Ithaca: Cornell University Press, 2004). 
${ }^{54}$ Barnett, op. cit., p. 558.

${ }^{55}$ Acharya, op. cit.; Peter Jackson, "Pierre Bourdieu, the 'cultural turn' and the practice of international history”, Review of International Studies, Vol. 34, No. 1 (2008), pp. 155-181; Laura Neack, "UN Peace-keeping : In the Interest of Community or Self ?", Journal of Peace Research, Vol. 32, No. 2 (1995), pp. 181-196; Roland Paris, "Peacekeeping and the Constraints of Global Culture", European Journal of International Relations, Vol. 9, No. 3 (2003), pp. 441-473; Wanda Vrasti, “The Strange Case of Ethnography and International Relations", Millennium, Vol. 37, No. 2 (2008), pp. 279-301.

${ }^{56}$ Iver B. Neumann, “ ‘A Speech That the Entire Ministry May Stand for’, or: Why Diplomats Never Produce Anything New", International Political Sociology, Vol. 1, No. 2 (2007), pp. 183-200, particularly pp. 193-197.

${ }^{57}$ Olivier Corten, Le droit contre la guerre. L'interdiction du recours à la force en droit international contemporain, Paris, Pedone, 2008.

${ }^{58}$ Barnett, op. cit., p. 574-575.

${ }^{59}$ Neumann, “A Speech That the Entire Ministry May Stand for”, op. cit.

${ }^{60}$ David Ambrosetti, "L’humanitaire comme norme du discours au Conseil de sécurité", Cultures \& Conflits, No. 60 (2005), pp. 39-62.

${ }^{61}$ During the public meeting of May 16, 1994, Karel Kovanda declared: "The crocodiles in the Kagera River and the vultures over Rwanda have seldom had it so good. They are feeding on the bodies of the thousands upon thousands of children and women, hundreds of whom were pregnant, and men who have been hacked to death during the past six weeks by what has turned out to be a most vicious regime. [...] This situation is being described as a humanitarian crisis as though it were a famine or perhaps a natural disaster. In the view of my delegation, the proper description is genocide." UN, official verbatim, New York, 16 May 1994, S/PV.3377, p. 15.

${ }^{62}$ Barnett, op. cit., p. 572.

${ }^{63}$ Ibid.

${ }^{64}$ Ibid., p. 560. In my research, I particularly deepened the French government's reactions, which expanded dramatically its communication toward media concerning Rwanda once the genocide began, given the military protection it provided to the Habyarimana regime before the genocide. David Ambrosetti, Normes et rivalités diplomatiques à l'ONU, op. cit. 
${ }^{65}$ Organization of African Unity, op. cit., p. 64 from $\S 10.12$ to $\S 10.15$, and p. $82 \S 12.36$; United Nations, Anand Panyarachun, A More Secure World: Our Shared Responsibility, Report of the High-level Panel on Threats, Challenges and Change, 2 December 2004, A/59/565, p. 23 §41, p. 34 §87.

${ }^{66}$ The French operation Turquoise triggered out strong debates and reluctances from delegations of emerging countries and the G-77, including China, and was endorsed by the UNSC thanks to the strong support of Madeleine Albright, despite five abstentions. See UN, official verbatim, New York, 22 June 1994, S/PV.3392. The other military operations mentioned above were better welcomed.

${ }^{67}$ David Ambrosetti, “Les opérations de paix de l'ONU face au risque d'un discrédit irrémédiable : la faiblesse et la sélectivité" [UN Peace Operations and the Risk of an Irremediable Discredit: Between Weakness and Selectivity], Studia Diplomatica, Vol. 59, No. 2 (2006), pp. 123-139. This evolution has also been noticed by Lise Morjé Howard, UN Peacekeeping in Civil Wars (Cambridge : Cambridge University Press, 2008), pp. 338339; Crocker, Hampson and Pamela Aall, Taming Intractable Conflicts, op. cit., p. 62 ; Paul Williams, « La Grande-Bretagne de Tony Blair et l'Afrique », in Politique africaine, 94, juin 2004, p. 116.

${ }^{68}$ As David Chandler also noticed. David Chandler, "The Security-Development Nexus and the Rise of "AntiForeign Policy' ", Journal of International Relations and Development, Vol. 10, No. 4 (2007), pp. 362-386. 